\title{
Perbandingan Penyelesaian Sengketa Perceraian Secara Mediasi di Pengadilan dan di Luar Pengadilan di Kabupaten Kampar
}

\author{
Rika Lestari \\ Fakultas Hukum Universitas Riau \\ Jl. Pattimura Nomor 9 Gobah Pekanbaru \\ syifa_richa@yahoo.co.id
}

\begin{abstract}
The problems studied in this research were: first, how is a divorce settlement through mediation in Religious Court of Bangkinang, Kampar Regency? Second, how is a divorce settlement through mediation outside the court of Kampar Regency? Third, what are the advantages and disadvantages of a divorce settlement through mediation outside and inside the court of Kampar Regency? The method used in this study was juridical sociological. The result concluded that first, the divorce settlement through mediation in Religious Court of Bangkinang had not yet optimally conducted. Second, the divorce settlement through mediation outside the court of Kampar Regency might take place due to good emotional bound between the parties in dispute and the mediators. Third, the advantages of the mediation process in divorce settlement in the court of Kampar Regency were confidential, low cost, and the existence of family spirit. Meanwhile, the disadvantages were the embarassment to the older members of the family and the indirect way of problem solving in which the elders dominantly put their opinions more than the parties in dispute. Moreover, the schedule to meet was uncertain because it needed to be synchronized to the schedules of the elders of each party in dispute. Also, there was no sytematic recording since it was usually conducted verbally.
\end{abstract}

Key words: Mediation, divorce, outside the court, inside the court

\begin{abstract}
Abstrak
Permasalahan dalam penelitian ini adalah: pertama, bagaimanakah penyelesaian sengketa perceraian melalui mediasi di Pengadilan Agama Bangkinang Kabupaten Kampar? Kedua, bagaimanakah penyelesaian sengketa perceraian secara mediasi di luar pengadilan di Kabupaten Kampar? Ketiga, apakah kelebihan dan kekurangan penyelesaian sengketa secara mediasi di luar dan di dalam pengadilan di Kabupaten Kampar? Metode yang digunakan dalam penelitian ini adalah yuridis sosiologis. Hasil penelitian menyimpulkan, pertama: penyelesaian sengketa perceraian secara mediasi di Pengadilan Agama Bangkinang belum berjalan maksimal. Kedua, penyelesaian sengketa perceraian secara mediasi di luar pengadilan di Kabupaten Kampar dapat terjadi karena secara emosional para pihak terikat hubungan yang baik dengan para mediator. Ketiga, kelebihan proses mediasi dalam kasus perceraian di Kabupaten Kampar, yaitu bersifat rahasia, tidak memakan biaya yang besar, serta adanya rasa kekeluargaan. Sedangkan kekurangannya karena rasa segan ke ninik mamak dan paman, tidak menukik pada akar masalah, Lebih dominan ninik mamak dalam mengemukakan pendapat, relatif tidak ada kepastian hari untuk bertemu karena harus menyesuaikan dengan jadwal ninik mamak dan paman masing-masing pihak. Notulensi tidak tercatat secara sistematis bahkan ada yang secara lisan.
\end{abstract}

Kata kunci: Mediasi, perceraian, di luar pengadilan, di pengadilan. 


\section{Pendahuluan}

Perkawinan merupakan institusi yang sangat penting dalam masyarakat. Eksistensi institusi ini adalah melegalkan hubungan hukum antara seorang lakilaki dengan seorang wanita ${ }^{1}$. Yang dimaksud dengan perkawinan adalah ikatan lahir batin antara pria dan seorang wanita sebagai suami istri dengan tujuan untuk membentuk keluarga (rumah tangga) yang bahagia dan kekal berdasarkan Ketuhanan Yang Maha Esa. ${ }^{2}$

Dalam kepustakaan mengartikan perkawinan sebagai aqad yang menghalalkan pergaulan dan membatasi hak dan kewajiban serta tolong menolong antara seorang laki-laki dan perempuan yang antara keduanya bukan muhrim. ${ }^{3}$ Esensi pengertian perkawinan yang dikemukakan pakar di atas adalah bahwa perkawinan sebagai lembaga hukum, baik karena apa yang ada di dalamnya, maupun karena apa yang terdapat di dalamnya. ${ }^{4}$ Oleh karena itu perkawinan juga merupakan salah satu hubungan hukum yang terjadi dalam masyarakat.

Dari sudut pandang lain yang menjadi tujuan perkawinan adalah untuk membentuk keluarga yang bahagia dan kekal berdasarkan Ketuhanan Yang Maha Esa. Ini berarti bahwa perkawinan itu berlangsung seumur hidup; cerai diperlukan syarat-syarat yang ketat dan merupakan jalan terakhir; suami istri membantu untuk mengembangkan diri. ${ }^{5}$

Akan tetapi dalam kenyataannya terkadang tujuan dari perkawinan tidak sesuai dengan yang diharapkan. Dengan berjalannya waktu perbedaan pendapat antara suami dan istri terkadang dapat memunculkan pertengkaran dalam rumah tangga. Pertengkaran tersebut bisa terjadi karena masalah ekonomi, suami tidak memberi nafkah lagi kepada istri, istri tidak patuh pada suami, adanya perselingkuhan, adanya kekerasan dalam rumah tangga. Ada kalanya persoalan-persoalan tersebut dapat diselesaikan secara damai antara suami istri sehingga perkawinan dapat dipertahankan. Akan tetapi, jika persoalan tersebut tidak dapat diselesaikan secara damai maka itulah yang menyebabkan perceraian antara suami istri.

\footnotetext{
${ }^{1}$ Salim HS., Pengantar Hukum Perdata Tertulis (BW), Sinar Grafika, Jakarta, 2005, hlm. 61.

${ }^{2}$ Pasal 1 Undang-Undang Nomor 1 Tahun 1974 tentang Perkawinan.

${ }^{3}$ Martiman Prodjohamidjojo, Hukum Perkawinan dalam Tanya Jawab, Cetakan Keenam, Indonesia Legal Center Publishing, Jakarta, 2011, hlm.15.

${ }^{4}$ Salim,..Loc.Cit.

${ }^{5}$ Ibid., hlm. 62.
} 
Upaya damai yang dilakukan untuk mempertahankan rumah tangga dapat dilakukan dengan musyawarah bersama antara suami dan istri, namun bisa juga melalui bantuan pihak ketiga untuk mendamaikannya, inilah yang dikenal dengan mediasi.

Mediasi pada dasarnya adalah negosiasi yang melibatkan pihak ketiga yang memiliki keahlian mengenai prosedur mediasi yang efektif, dapat membantu dalam situasi konflik untuk mengkoordinasikan aktifitas mereka sehingga lebih efektif dalam proses tawar menawar, bila tidak ada negosiasi, tidak ada mediasi. ${ }^{6} \mathrm{Di}$ samping itu, mediator juga harus mampu menjaga kepentingan para pihak yang bersengketa secara adil dan sama, sehingga menumbuhkan kepercayaan (trust) dari para pihak yang bersengketa ${ }^{7}$.

Penyelesaian sengketa secara mediasi telah dikenal di Indonesia sejak zaman dahulu kala. Untuk menyelesaikan permasalahan-permasalahan yang terjadi dalam masyarakat, maka forum lembaga adat biasanya menyelesaikan sengketa yang terjadi diantara anggota masyarakat yang mereka pimpin. Apabila sengketa yang terjadi tersebut tidak dapat lagi diselesaikan secara mediasi oleh forum lembaga adatnya, maka sengketa akan dibawa ke pengadilan. Salah satu contoh peran pihak ketiga dalam menyelesaikan kasus perceraian adalah yang biasa digunakan oleh ninik mamak (para tetua adat) yang ada di Kecamatan Tambang Kabupaten Kampar Provinsi Riau. Pada 2012 terdapat 7 (tujuh) kasus perceraian yang diajukan ke ninik mamak, 5 diantaranya dapat diselesaikan melalui mediasi oleh ninik mamak, dan hanya 2 perkara masuk ke Pengadilan Agama Bangkinang, karena tidak bisa diselesaikan oleh ninik mamak lagi. ${ }^{8}$

Secara yuridis keberadaan mediasi di luar pengadilan di Indonesia telah diatur dalam Undang-Undang Nomor 30 Tahun 1999 tentang Arbitrase dan Alternatif Penyelesaian Sengketa. Pada Pasal 6 ayat (3), disebutkan bahwa mediasi merupakan proses kegiatan sebagai kelanjutan dari gagalnya negosiasi yang dilakukan oleh para pihak menurut ketentuan Pasal 6 ayat (2) Undang-Undang Nomor 30 Tahun 1999. Dengan adanya Undang-undang ini eksistensi tentang mediasi di Indonesia semakin kuat.

${ }^{6}$ Mahkamah Agung RI, Mediasi dan Perdamaian, MA-RI, Jakarta, 2004, hlm. 61, sebagaimana dikutip oleh Nurnaningsih Amriani, Mediasi Alternatif Penyelesaian Sengketa Perdata di Pengadilan, RajaGrafindo Persada, Jakarta, 2012, hlm 28.

${ }^{7}$ Syahrizal Abbas, Mediasi dalam PerspektifHukum Syariah, Hukum Adat, dan Hukum Nasional, Kencana Prenada Media Group, Jakarta, 2009, hlm. 2.

${ }^{8}$ Abdul Salam, "Pelaksanaan Mediasi dalam Perkara Perceraian pada Masyarakat Adat di Desa Kualu Kecamatan Tambang Kabupaten Kampar”, Skripsi, 2013, hlm. 73. 
Perkembangan saat ini mediasi juga dikenal di pengadilan, sebagaimana ditegaskan dalam Peraturan Mahkamah Agung No. 1 Tahun 2008 tentang Prosedur Mediasi di Pengadilan, mediasi menjadi terkoneksi dengan lembaga peradilan di Indonesia. Dalam ketentuan Perma tersebut dijelaskan bahwa mediasi wajib dilakukan oleh para pihak yang berperkara secara perdata di pengadilan yang dilakukan pada hari sidang pertama. Tujuan dilaksanakannya prosedur mediasi di pengadilan ini adalah untuk menciptakan perdamaian di antara para pihak yang sedang bersengketa. Bahkan, di setiap tingkatan peradilan upaya mediasi harus ditempuh dalam menyelesaikan sengketa keperdataan.

Oleh sebab itu, peneliti tertarik untuk meneliti tentang "Perbandingan Penyelesaian Sengketa Perceraian secara Mediasi di Pengadilan dan di Luar Pengadilan di Kabupaten Kampar".

\section{Rumusan Masalah}

Adapun rumusan masalah dalam penelitian ini adalah: pertama, bagaimanakah penyelesaian sengketa perceraian melalui mediasi di Pengadilan Agama Bangkinang Kabupaten Kampar? Kedua, bagaimanakah penyelesaian sengketa perceraian secara mediasi di luar pengadilan di Kabupaten Kampar? Ketiga, apakah kelebihan dan kekurangan penyelesaian sengketa secara mediasi di luar dan di dalam pengadilan di Kabupaten Kampar?

\section{Tujuan Penelitian}

Penelitian ini bertujuan untuk: pertama, mempelajari penyelesaian sengketa perceraian melalui mediasi di Pengadilan Agama Bangkinang Kabupaten Kampar. Kedua, untuk mengetahui penyelesaian sengketa perceraian secara mediasi di luar pengadilan di Kabupaten Kampar. Ketiga, untuk menelaah kelebihan dan kekurangan penyelesaian sengketa secara mediasi di luar dan di dalam pengadilan di Kabupaten Kampar. 


\section{Metode Penelitian}

Jenis penelitian yang akan digunakan adalah penelitian yuridis sosiologis, yaitu melihat proses bekerjanya hukum dalam masyarakat ${ }^{9}$ berdasarkan Undang-Undang Nomor 30 Tahun 1999 tentang Arbitrase dan Alternatif Penyelesaian Sengketa dan Peraturan Mahkamah Agung No. 1 Tahun 2008 tentang Mediasi di Pengadilan. Lokasi Penelitian berada di Kabupaten Kampar dan di Pengadilan Agama Bangkinang. Data yang diperoleh langsung dari sumber pertama, yakni para Ninik Mamak di Kabupaten Kampar, Mediator di Pengadilan Agama Bangkinang. Data yang mencakup dokumen-dokumen resmi, peraturan perundang-undangan, bukubuku, hasil-hasil penelitian yang berwujud laporan, buku harian.

Dalam penelitian ini, analisis yang digunakan adalah analisis kualitatif, ${ }^{10}$ yaitu uraian yang dilakukan terhadap data yang terkumpul dengan tidak menggunakan angka-angka tetapi berdasarkan peraturan perundang-undangan dan pendapat pakar hukum, selanjutnya peneliti menerangkan dengan jelas dan rinci melalui interprestasi data dengan menghubungkan keterkaitan data yang satu dengan yang lainnya dan dianalisa berdasarkan teori hukum maupun ketentuan hukum yang berlaku dan pendapat para ahli, untuk kemudian menarik kesimpulan dengan cara induktif yakni penarikan kesimpulan dari hal-hal yang bersifat khusus kepada halhal yang bersifat umum.

\section{Hasil Penelitian dan Pembahasan}

\section{Beberapa cara Penyelesian Sengketa}

\section{Penyelesaian di Pengadilan}

Tidak ada negara yang tidak menginginkan adanya ketertiban tatanan di dalam masyarakat. Setiap negara mendambakan adanya ketenteraman dan keseimbangan tatanan di dalam masyarakat, yang sekarang lebih populer disebut "stabilitas nasional'. Kepentingan manusia, baik sebagai individu maupun kelompok, karena selalu terancam oleh bahaya-bahaya di sekelilingnya, memerlukan perlindungan dan harus dilindungi. Kepentingan manusia akan terlindungi apabila masyarakatnya

\footnotetext{
${ }^{9}$ Bambang Sunggono, Metode Penelitian Hukum, RajaGrafindo Persada, Jakarta, 1996, hlm. 43.

${ }^{10}$ Ibid., hal. 32.
} 
tertib dan masyarakatnya akan tertib apabila terdapat keseimbangan tatanan di dalam masyarakat. Setiap saat keseimbangan tatanan dalam masyarakat dapat terganggu oleh bahaya-bahaya di sekelilingnya ${ }^{11}$.

Masyarakat berkepentingan bahwa keseimbangan yang terganggu itu dipulihkan kembali. Salah satu unsur untuk menciptakan atau memulihkan keseimbangan tatanan di dalam masyarakat adalah penegakan hukum atau peradilan yang bebas/mandiri, adil dan konsisten dalam melaksanakan atau menerapkan peraturan hukum yang ada dan dalam menghadapi pelanggaran hukum, oleh suatu badan yang mandiri, yaitu pengadilan. Bebas/mandiri dalam mengadili dan bebas/mandiri dari campur tangan pihak ekstra yudisiil. Kebebasan pengadilan, hakim atau peradilan merupakan asas universal yang terdapat di manamana. Kebebasan peradilan merupakan dambaan setiap bangsa atau negara. Di mana-mana pada dasarnya dikenal asas kebebasan peradilan, hanya isi atau nilai kebebasannya yang berbeda. Isi atau nilai kebebasan peradilan di negara-negara Eropa Timur dengan Amerika berbeda, isi dan nilai kebebasan peradilan di Belanda dengan di Indonesia tidak sama, walaupun, semuanya mengenal asas kebebasan peradilan; tidak ada negara yang rela dikatakan bahwa negaranya tidak mengenal kebebasan peradilan atau tidak ada kebebasan peradilan di negaranya. Tidak ada bedanya dengan pengertian hak asasi manusia, yang sekarang sedang banyak disoroti; hak asasi bersifat universal, semua negara "mengklaim" menghormati hakhak asasi manusia, tetapi nilai dan pelaksanaannya berbeda satu sama lain. ${ }^{12}$

Adil, tidak hanya bagi pencari keadilan saja tetapi juga bagi masyarakat, tidak memihak, objektif, tidak a priori serta konsisten, ajeg dalam memutuskan, dalam arti perkara yang sama (serupa, sejenis) harus diputus sama (serupa, sejenis) pula. Tidak ada dua perkara yang sama. Setiap perkara harus ditangani secara individual (to each his own), secara kasuistis dengan mengingat bahwa motivasi, situasi, kondisi dan waktu terjadinya tidak sama. Akan tetapi kalau ada dua perkara yang sejenis atau serupa maka harus diputus sejenis atau serupa pula. Ini merupakan "postulaat keadilan": perkara yang serupa diputus sama. ${ }^{13}$

\footnotetext{
${ }^{11}$ Sudikno Mertokusumo, Sistem Peradilan di Indonesia, 24 Maret 2008, http://sudiknoartikel.blogspot.com/ 2008/03/sistem-peradilan-di-indonesia.html, diakses 29 November 2013.

${ }^{12}$ Masyhur Effendi, H.A.-, 1994, Hak. Asasi Manusia Dalam Huk.um Nasional dan Intemasional, Ghalia Indonesia, sebagaimana dikutip oleh Sudikno Mertokusumo,.Ibid.

${ }^{13}$ Nieuwenhuis, J.H.-, Legitimatie en heuristik van het rechterlijk oordeel, Themis 1976/6, sebagaimana dikutip oleh Sudikno Mertokusumo, Ibid.
} 
Kalau perkara yang serupa diputus berbeda maka akan dipertanyakan: dimanakah kepastian hukumnya, apa yang lalu dapat dijadikan pegangan bagi para pencari keadilan, dimana keadilannya?

Oleh Roscoe Pound dikatakan bahwa adanya kepastian hukum memungkinkan adanya "predictability". ${ }^{14}$ Akan tetapi sebuah keputusan yang ditetapkan atau diputuskan oleh hakim tidak saja memperhatikan aspek kepastian hukum semata, tetapi juga memperhatikan asas kemanfaatan dan asas keadilan.

\section{Penyelesaian Sengketa di Luar Pengadilan Secara Mediasi}

Pengertian mediasi yang agak luas diberikan oleh The National Alternative Dispute Resolution Advisory Council:

Mediation is a process in which the parties to a dis-pute, with the assistance of a dispute resolution practit-ioner (a mediator), identify the dispute issues, develop options, consider alternatives and endeavour to reach an agreement. The mediator has no advisory or determinative role in regard to the content of dispute or the outcome of its resolution, but may advise on or determine the process of mediation whereby resolution is attempted". ${ }^{15}$

Pengertian mediasi ini dapat diklasifikasikan ke dalam tiga unsur penting yang saling terkait satu sama lain. Ketiga unsur tersebut berupa: ciri mediasi, peran me-diator, dan kewenangan mediator. Dalam ciri mediasi tergambar bahwa mediasi berbeda dengan berbagai ben-tuk penyelesaian sengketa lainnya, terutama dengan al-ternatif penyelesaian sengketa di luar pengadilan seperti arbitrase. Dalam mediasi, seorang mediator berperan membantu para pihak yang bersengketa dengan melakukan identifikasi persoalan yang dipersengketakan, mengembangkan pilihan, dan mempertimbangkan alternatif yang dapat ditawarkan kepada para pihak untuk men-capai kesepakatan. Mediator dalam menjalankan perannya hanya memiliki kewenangan untuk memberikan saran atau menentukan proses mediasi dalam mengupa-yakan penyelesaian sengketa. Mediator tidak memiliki kewenangan dan peran menentukan dalam kaitannya dengan isi persengketaan, ia hanya menjaga bagaimana proses mediasi dapat berjalan, sehingga menghasilkan kesepakatan (agreement) dari para pihak. ${ }^{16}$

\footnotetext{
${ }^{14}$ Peter Mahmud Marzuki, Pengantar Ilmu Hukum, Prenada Media Group, Jakarta, 2009: hlm. 158.

${ }^{15}$ David Spencer dan Michael Brogan, Mediation Law and Practice, Cambridge, Cambridge University Press, 2006, hlm. 9. Sebagaimana dikutip dalam Syahrizal... Ibid., hlm. 6.

${ }^{16}$ Ibid., hlm. 7.
} 
Dalam Black's Law Dictionary, dikatakan bahwa: ${ }^{17}$ "Mediation is private, informal dispute resolution process in which a neutral third person, the mediator, helps, disputing parties to reach an agreement". Dalam Kamus Besar Bahasa Indonesia, kata mediasi diberi arti sebagai proses pengikutsertaan pihak ketiga dalam penyelesaian suatu perselisihan sebagai penasihat. ${ }^{18}$ Dari rumusan tersebut dapat kita simpulkan bahwa dalam mediasi ada keterlibatan pihak ketiga atau pihak lain dalam menyelesaikan perkara di antara para pihak yang bersengketa. Kemudian pihak ketiga itu hanya sebagai penasehat tidak memiliki kewenangan untuk memutuskan suatu masalah yang sedang dipersengketakan.

Dalam Pasal 6 ayat (3) Undang-Undang 30 Tahun 1999 tentang Arbitrase dan Alternatif Penyelesaian Sengketa, disebutkan bahwa: “Dalam hal sengketa atau beda pendapat sebagaimana dimaksud dalam ayat (2) tidak dapat diselesaikan, maka atas kesepakatan tertulis para pihak, sengketa atau beda pendapat diselesaikan melalui bantuan seorang atau lebih penasehat ahli maupun melalui seorang mediator". Dalam undang-undang ini tidak secara tegas memberikan pengertian mediasi, hanya menyebutkan apabila ada sengketa maka dapat dibantu oleh pihak ketiga atau mediator.

Sedangkan menurut Laurence Bolle menyatakan "mediation is a decision making process in which the parties are-assisted by a me-diator; the mediator attempt to improve the process of decision making and to assist the parties the reach an out-come to which of them can assent." ${ }^{19}$ Sedangkan J. Folberg dan A. Taylor memaknai mediasi dengan “... the process by which the participants, together with the assistance of a neutral persons, systematically isolate dispute in order to develop options, consider alternative, and reach consen-sual settlement that will accommodate their needs. ${ }^{20}$

Pengertian mediasi yang diberikan dua ahli di atas, lebih menggambarkan esensi kegiatan mediasi dan peran mediator sebagai pihak ketiga. Bolle menekankan bah-wa mediasi adalah proses pengambilan keputusan yang dilakukan para pihak dengan dibantu pihak ketiga se-bagai mediator. Pernyataan Bolle menunjukkan

\footnotetext{
hlm. 81.

${ }^{17}$ Dikutip dari Rachmadi Usman, Pilihan Penyelesaian Sengketa di Luar Pengadilan, Citra Aditya Bakti, Bandung,

${ }^{18}$ Tim Penyusun Kamus Pusat Pembinaan dan Pengembangan Bahasa, Ka-mus Besar Bahasa Indonesia, Departemen Pendidikan dan Kebudayaan, Jakarta, 1988, hlm. 569.

${ }^{19}$ Laurence Bolle, Mediation: Principles, Process, and Practice, New York, 1996, hlm. 1. Sebagaimana dikutip oleh Syahrizal Abbas, Mediasi dalam ...,Op. Cit., hlm. 4.

${ }^{20}$ J. Folberg dan A. Taylor, Mediation: A Comprehensive Guide to Resolving Conflict Without Litigation, Cambridge University Press, Cambridge, 1984, hlm. 7. Sebagaimana dikutip oleh Syahrizal Abbas, Ibid.
} 
bahwa kewenangan pengambilan keputusan sepenuhnya berada di tangan para pihak, dan mediator hanyalah membantu para pihak di dalam proses pengambilan keputusan tersebut. Kehadiran mediator menjadi amat penting karena ia dapat membantu dan mengupayakan proses pengam-bilan keputusan menjadi lebih baik, sehingga menghasilkan outcome yang dapat diterima oleh mereka yang bertikai.

J. Folberg dan A. Taylor lebih menekankan konsep mediasi pada upaya yang dilakukan mediator dalam men-jalankan kegiatan mediasi. ${ }^{21}$ Kedua ahli ini menyatakan bahwa penyelesaian sengketa melalui jalur mediasi dilakukan secara bersama-sama oleh pihak yang bersengke-ta dan dibantu oleh pihak yang netral. Mediator dapat mengembangkan dan menawarkan pilihan penyelesaian sengketa, dan para pihak dapat pula mempertimbangkan tawaran mediator sebagai suatu alternatif menuju kesepakatan dalam penyelesaian sengketa. Alternatif penyelesaian yang ditawarkan mediator diharapkan mampu mengakomodasikan kepentingan para pihak yang bersengketa. Mediasi dapat membawa para pihak mencapai kesepakatan tanpa merasa ada pihak yang menang atau hak-hak yang kalah (win-win solution).

\section{Beberapa Model mediasi}

Lawrence Boulle, seorang profesor dalam ilmu hukum dan Direktur Dispute Resolution Centre-Bond University, membagi mediasi dalam sejumlah model yang tujuannya untuk menemukan peran mediator dalam melihat posisi sengketa dan peran para pihak dalam upaya penyelesaian sengketa. Boulle menyebutkan ada empat model mediasi, yaitu settlement mediation, facilitative mediation, trans-formative mediation dan evaluative mediation ${ }^{22}$.

Settlement mediation dikenal sebagai mediasi komp-romi merupakan mediasi yang tujuan utamanya adalah untuk mendorong terwujudnya kompromi dari tuntutan kedua belah pihak yang sedang bertikai. Dalam mediasi model ini, tipe mediator yang dikehendaki adalah yang berstatus tinggi, sekalipun tidak terlalu ahli dalam proses dan teknik-teknik mediasi. Adapun peran yang dapat dimainkan oleh mediator adalah menentukan "bottom lines" dari disputan dan secara persuasif mendorong kedua belah pihak bertikai untuk sama-sama menurunkan posisi mereka ke titik kompromi.

\footnotetext{
${ }^{21}$ Ibid., hlm. 7-8.

${ }^{22}$ Ibid., hlm. 31.
} 
Model settlement mediation mengandung sejumlah prinsip antara lain: ${ }^{23} 1$. Mediasi dimaksudkan untuk mendekatkan perbeda-an nilai tawar atas suatu kesepakatan; 2. Mediator hanya terfokus pada permasalahan atau posisi yang dinyatakan para pihak; 3. Posisi mediator adalah menentukan posisi "bottom line" para pihak dan melakukan berbagai pendekatan untuk mendorong para pihak mencapai titik kompromi; 4. Biasanya mediator adalah orang yang memiliki status yang tinggi dan model ini tidak menekankan kepada keahlian dalam proses atau teknik mediasi.

Facilitative mediation, yang juga disebut sebagai me-diasi yang berbasis kepentingan (interest-based) dan problem solving yang bertujuan untuk menghindarkan para pihak yang bersengketa dari posisi mereka dan menegosiasikan kebutuhan dan kepentingan para pihak dari hak-hak legal mereka secara kaku. ${ }^{24}$ Dalam model ini mediator harus ahli dalam proses mediasi dan menguasai teknik-teknik mediasi, meskipun penguasaan materi tentang hal-hal yang dipersengketakan tidak terlalu penting. Dalam hal ini sang mediator harus dapat memimpin proses mediasi dan mengupayakan dialog yang konstruktif di antara para pihak yang bersengketa, serta meningkatkan upaya-upaya negosiasi dan upaya kesepakatan.

Model facilitative mediation, mengandung sejumlah prinsip antara lain: ${ }^{25} 1$. Prosesnya lebih terstruktur; 2. Penekanannya lebih ditujukan kepada kebutuhan dan kepentingan para pihak yang berselisih; 3. Mediator mengarahkan para pihak dari positional negotiation ke interest based negotiation yang mengarahkan kepada penyelesaian yang saling menguntungkan; 4. Mediator mengarahkan para pihak untuk lebih kreatif dalam mencari alternatif penyelesaian; 5. Mediator perlu memahami proses dan teknik mediator tanpa harus ahli dalam bidang yang diperselisihkan.

Transformative mediation, juga dikenal sebagai mediasi terapi dan rekonsiliasi. Mediasi model ini menekankan untuk mencari penyebab yang mendasari munculnya permasalahan di antara para pihak yang bersengketa, dengan pertimbangan untuk meningkatkan hubungan di antara mereka melalui pengakuan dan pemberdayaan sebagai dasar resolusi konflik dari pertikaian yang ada. ${ }^{26}$ Dalam model ini sang mediator harus dapat mengguna-kan terapi dan teknik profesional

\footnotetext{
${ }^{23}$ Ibid., hlm. 32.

${ }^{24}$ Allan J. Stitt, Op. Cit., hlm. 2. Dikutip Syahrizal Abbas, Ibid., hlm. 32.

${ }^{25}$ Ibid., hlm. 33.

${ }^{26}$ Robert A.Baruch Bush dan Joseph P.Folger, The Promise of Mediation: Transformative Approach to Conflict, (USA: Willey, 2004), hlm. 41. Dikutip Syahrizal Abbas, Ibid., hlm. 33.
} 
sebelum dan selama proses mediasi serta mengangkat isu relasi/hubungan melalui pemberdayaan dan pengakuan.

Model transformatif atau lebih dikenal dengan theu-rapic model mengandung sejumlah prinsip antara lain: ${ }^{27} 1$. fokus pada penyelesaian yang lebih komprehensif dan tidak terbatas hanya pada penyelesaian sengketa tetapi juga rekonsiliasi antara para pihak; 2. proses negosiasi yang mengarah kepada pengambilan keputusan tidak akan dimulai, bila masalah hubungan emosional para pihak yang berselisih belum diselesaikan; 3 . fungsi mediator adalah untuk mendiagnosis penyebab konflik dan menanganinya berdasarkan aspek psikologis dan emosional, hingga para pihak yang berse-lisih dapat memperbaiki dan meningkatkan kembali hubungan mereka; 4. mediator diharapkan lebih memiliki kecakapan dalam "counseling" dan juga proses serta teknik mediasi; 5 . penekanannya lebih ke terapi, baik tahapan pramediasi atau kelanjutannya dalam proses mediasi.

Evaluative mediation, yang juga dikenal sebagai mediasi normatif merupakan model mediasi yang bertujuan untuk mencari kesepakatan berdasarkan hak-hak legal dari para pihak yang bersengketa dalam wilayah yang diantisipasi oleh pengadilan. ${ }^{28}$ Peran yang bisa dijalankan oleh mediator dalam hal ini adalah memberikan informasi dan saran serta persuasi kepada para disputans dan memberikan prediksi tentang hasil-hasil yang akan dida-patkan. ${ }^{29}$

Model evaluasi (evaluative model) juga mengandung sejumlah prinsip: 1. Para pihak berharap bahwa mediator akan menggunakan keahlian dan pengalamannya untuk mengarah-kan penyelesaian sengketa ke suatu kisaran yang telah diperkirakan terhadap masalah tersebut; 2. Fokusnya lebih tertuju kepada hak (rights) melalui standar penyelesaian atas kasus yang serupa; 3 . Mediator harus seorang ahli dalam bidang yang diperselisihkan dan dapat juga terkualifikasi secara legal. Mediator tidak harus memiliki keahlian dalam proses dan teknik mediasi; 4 . Kecenderungan mediator memberikan jalan keluar dan informasi legal guna mengarahkan para pihak menuju suatu hasil akhir yang pantas dan dapat diterima oleh keduanya.

\footnotetext{
${ }^{27}$ Ibid., hlm. 34.

${ }^{28}$ Allan J. Stitt, Op, cit., hlm. 2. Dikutip Syahrizal Abbas, Ibid.

${ }^{29}$ David Spencer dan Michael Brogan, Op. Cit., hlm. 101-103. Sebagaimana dikutip oleh Syahrizal Abbas, Ibid., hlm. 35 .
} 


\section{Mediasi di Pengadilan Agama Bangkinang}

Laju perkembangan dunia dan era globalisasi mengharuskan adanya suatu sistem/lembaga penyelesaian sengketa yang dapat menyesuaikan dengan laju perkembangan permasalahan dalam masyarakat yang semakin kompleks. Hal ini berkaitan langsung dengan munculnya tuntutan untuk menyelesaikan setiap sengketa tidak hanya dalam dunia usaha tetapi juga dalam permasalahan yang bersinggungan dengan penegakan hukum di berbagai bidang secara cepat, efektif, dan efisien. Harus ada lembaga yang dapat diterima sekaligus memiliki kemampuan sistem penyelesaian sengketa yang cepat dan biaya murah serta sejalan dengan tuntutan yang tengah berkembang di masyarakat. Pengintegrasian mediasi ke dalam proses beracara di pengadilan dapat menjadi salah satu instrumen efektif mengatasi masalah penumpukan perkara di pengadilan serta memperkuat dan memaksimalkan fungsi lembaga pengadilan dalam penyelesaian sengketa di samping proses pengadilan yang bersifat memutus (ajudikatif).

Mahkamah Agung mempunyai komitmen yang tinggi untuk meningkatkan keberhasilan perdamaian melalui mediasi di pengadilan sebagai implementasi dari Pasal 130 HIR dan Pasal 158 RBG. Penyelesaian sengketa perdata di pengadilan merupakan fenomena global yang terjadi di seluruh pengadilan di dunia dan mempunyai tingkat keberhasilan yang cukup tinggi di beberapa negara antara lain Jepang, Amerika Serikat, Australia, Philipina dan Singapore.

Dari hasil evaluasi Peraturan Mahkamah Agung (Perma) Nomor 2 Tahun 2003 tentang Prosedur Mediasi di Pengadilan, pada 31 Juli 2008 Mahkamah Agung telah mengeluarkan Perma Nomor 1 Tahun 2008 sebagai penyempurnaan peraturan sebelumnya yang diharapkan dapat menjadi pedoman pelaksanaan mediasi di dalam pengadilan maupun di luar pengadilan sambil menunggu lahirnya undangundang tentang mediasi. ${ }^{30}$

Dilihat dari sejarahnya pengaturan tentang mediasi ini telah tercermin dari ketentuan HIR Pasal 130 dan Rbg Pasal 154 telah mengatur lembaga perdamaian. Hakim wajib terlebih dahulu mendamaikan para pihak yang berperkara sebelum perkaranya diperiksa. Setelah itu lahir SEMA Nomor 1 Tahun 2002 tentang Pemberdayaan Lembaga Perdamaian dalam Pasal 130 HIR/154 Rbg. PERMA Nomor

${ }^{30}$ D.S. Dewi, Hakim Mediator (Ketua Pengadilan Negeri Stabat), makalah tentang "Implementasi PERMA Nomor 1 Tahun 2008 Tentang Prosedur Mediasi Pengadilan”, pada Pelatihan Mediator yang diselenggarakan oleh IICT bekerjasama dengan Fakultas Hukum Universitas Riau pada Tahun 2011. 
02 Tahun 2003 tentang Prosedur Mediasi di Pengadilan. PERMA Nomor 01 Tahun 2008 tentang Prosedur Mediasi di Pengadilan. Kemudian dalam Pasal 6 UndangUndang Nomor 30 Tahun 1999 tentang Arbitrase dan Alternatif Penyelesaian Sengketa.

Di samping peraturan perundang-undangan di atas terdapat beberapa peraturan perundang-undangan yang lain yang mengatur tentang mediasi yaitu: Undang-Undang Nomor 32 Tahun 2009 tentang Lingkungan Hidup, Undang-Undang Nomor 18 Tahun 1999 tentang Jasa Konstruksi, Undang-Undang Nomor 8 Tahun 1999 tentang Perlindungan Konsumen, Undang-Undang Nomor 30 Tahun 2000 tentang Rahasia Dagang, Undang-Undang Nomor 31 Tahun 2000 tentang Desain Industri, UndangUndang Nomor 14 Tahun 2001 tentang Paten, Undang-Undang Nomor 15 Tahun 2001 tentang Merk, Undang-Undang Nomor 2 Tahun 2004 tentang Pengadilan Hubungan Industrial, Undang-Undang Nomor 37 Tahun 2008 tentang Ombudsman RI, UndangUndang Nomor 39 Tahun 1999 tentang Hak Asasi Manusia, Undang-Undang Nomor 40 Tahun 1999 tentang Pers, Undang-Undang Nomor 32 Tahun 2009 Pasal 85 ayat (3) tentang Lingkungan Hidup, Undang-Undang Nomor 36 Tahun 2009 Pasal 29 tentang Kesehatan, Undang-Undang Nomor 14 Tahun 2008 Pasal 40 tentang Keterbukaan Informasi, Undang-Undang Nomor 25 Tahun 2009 tentang Pelayanan Publik, Peraturan B.I. Nomor 8/5/PBI/2006 tentang Pembentukan Lembaga Mediasi Perbankan.

Dalam PERMA Nomor 01 Tahun 2008 tentang Prosedur Mediasi di Pengadilan disebutkan bahwa Mediasi adalah cara penyelesaian sengketa melalui proses perundingan untuk memperoleh kesepakatan para pihak dengan dibantu oleh mediator (Pasal 1 ayat (7)). Sedangkan yang dimaksud dengan Mediator adalah pihak netral yang membantu para pihak dalam proses perundingan guna mencari berbagai kemungkinan penyelesaian sengketa tanpa menggunakan cara memutus atau memaksakan sebuah penyelesaian (Pasal 1 ayat (6)).

Tidak ditempuhnya proses mediasi berdasarkan Perma ini merupakan pelanggaran terhadap ketentuan Pasal 130 HIR/154 RBg yang mengakibatkan putusan batal demi hukum (ayat (3)). Hakim dalam pertimbangan putusannya wajib menyebutkan bahwa perkara yang bersangkutan telah diupayakan perdamaian melalui mediasi dengan menyebutkan nama mediator yang bersangkutan (ayat (4)).

Dilihat jumlah kasus perceraian yang masuk ke Pengadilan Agama ${ }^{31}$ adalah sebagai berikut:

${ }^{31}$ Wawancara dengan Tommy Andesta Siahaan, Staf Biro Hukum Pengadilan Agama Bangkinang, tanggal 18 November 2013. 
Tabel 1

Banyak Perkara Perceraian di Pengadilan Agama Bangkinang

\begin{tabular}{|l|l|l|}
\hline No & \multicolumn{1}{|c|}{ Perkara } & \multicolumn{1}{c|}{ Tahun } \\
\hline 1 & $\begin{array}{l}\text { Perkara Cerai Talak 225 Perkara; } \\
\text { Perkara Cerai Gugat 508 Perkara; + }\end{array}$ & 2012 \\
2 & $\begin{array}{l}\text { Jumlah Perkara 733 Perkara } \\
\text { Perkara Cerai Talak 167 Perkara; } \\
\text { Perkara Cerai Gugat 396 Perkara; + }\end{array}$ & (Januari-November ) 2013 \\
\hline Jumlah Perkara 563 Perkara.
\end{tabular}

Sumber Data: Pengadilan Agama Bangkinang 2012-2013

Jika dilihat dari jumlah perkara perceraian di Pengadilan Agama Bangkinang semakin menurun dari 2012 berjumlah 733 perkara, menurun menjadi 563 perkara. Walaupun jumlah kasus perceraian sudah menurun pada tahun 2013 akan tetapi angka perceraian yang terjadi dalam masyarakat tergolong masih cukup tinggi. Oleh sebab itu upaya-upaya penurunan angka perceraian melalui berbagai cara seperti penyuluhan dan mediasi perlu ditingkatkan oleh pemerintah.

Berdasarkan hasil wawancara dengan salah satu hakim mediator bersertifikat, ${ }^{32}$ menyatakan bahwa tidak semua sengketa diselesaikan dengan mediasi, mediasi hanya dilaksanakan apabila hadir kedua belah pihak yang bersengketa, apabila tidak hadir salah satu pihak langsung diambil keputusan verstek terkait mediasinya, yang menjadi sengketa biasanya terkait sengketa harta bersama, waris dan lain-lain.

Dari hasil wawancara tersebut upaya untuk dilakukannya mediasi selalu diupayakan oleh Hakim Pengadilan Agama Bangkinang, akan tetapi apabila salah satu pihak tidak hadir tentu proses mediasi tidak dapat dilaksanakan. Memang jika dilihat dari penyelesaian perkara perceraian, adakalanya salah satu pihak tidak hadir ke persidangan untuk mengikuti proses pemeriksaan perkara. Hal ini bisa saja diakibatkan oleh keinginan yang kuat dari masing-masing pihak untuk bercerai dan tidak dimungkinkan untuk bersatu kembali. Walaupun demikian supaya keputusan hakim tidak batal demi hukum sesuai dengan PERMA Nomor 1 Tahun 2008 tentang Prosedur Mediasi di Pengadilan, maka haruslah disebutkan dalam keputusannya bahwa telah dilakukan upaya mediasi tetapi upaya tersebut gagal karena ketidakhadiran salah satu pihak.

${ }^{32}$ Wawancara dengan Drs. Sulem Ahmad, SH., MA, Hakim Mediator bersertifikat, pada 18 November 2013. 
Hal ini diperkuat dari hasil wawancara dengan salah satu hakim di atas dimana beliau menyatakan bahwa semua putusan Pengadilan Agama tentang kasus perceraian menggunakan mediasi sebelum memeriksa perkara. Karena wajib bagi hakim untuk menyampaikan penyelesaian mediasi, dan ini diatur dalam PERMA No. 1 Tahun 2008 tentang Mediasi, dan semua kasus perceraian di Pengadilan Agama yang masuk disampaikan untuk menyelesaikan permasalahan mereka dengan jalur mediasi, hanya saja tidak semua perkara yang kemudian menjalankan proses mediasi, karena pengetahuan para pihak yang berkeinginan keras untuk bercerai, selain itu ketidakhadiran para pihak dalam sidang pertama dalam penyampaian penyelesaian melalui mediasi.

Ketika ditanya tentang apakah dalam putusan dijelaskan tentang proses mediasi, Sulem Ahmad menjawab ada dijelaskan tentang proses mediasi, proses mediasi dimuat di dalam duduk perkara, dan bagian pertimbangan hukum dari putusan Perkara.

Lebih lanjut ditanyakan tentang tanggapan hakim tentang ketentuan PERMA Nomor 1 Tahun 2008 tentang Prosedur Mediasi yang menyebutkan bahwa apabila putusan hakim tidak menempuh jalur mediasi maka putusan Batal Demi Hukum, Sulem Ahmad menyatakan bahwa sangat baik adanya penyelesaian secara mediasi guna menyelesaikan perkara perceraian di Pengadilan Agama, hanya saja dalam pelaksanaannya sering dijumpai kegagalan dikarenakan kurangnya pengetahuan masyarakat akan proses dalam Pengadilan yang masih mengupayakan perdamaian melalui mediasi, dan kurang aktifnya para pihak mengikuti proses persidangan perkara di pengadilan. ${ }^{33}$

Kemudian Sulem Ahmad menambahkan, bahwa hasil mediasi yang mencapai kata sepakat dituangkan dalam kesepakatan perdamaian. ${ }^{34}$ Yang dimaksud dengan kesepakatan perdamaian adalah dokumen yang memuat syarat-syarat yang disepakati oleh para pihak guna mengakhiri sengketa yang merupakan hasil dari upaya perdamaian dengan bantuan seorang mediator atau lebih berdasarkan Peraturan ini. ${ }^{35}$ Kesepakatan perdamaian inilah menjadi dasar untuk pembuatan akta kompromis (perdamaian). Akta perdamaian adalah akta yang memuat isi kesepakatan perdamaian dan putusan hakim yang menguatkan kesepakatan

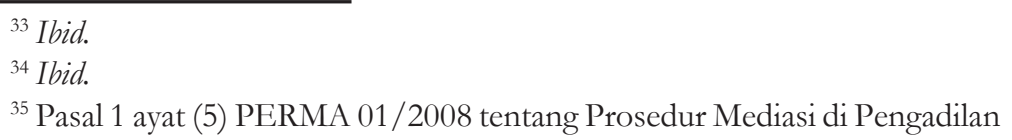


perdamaian tersebut yang tidak tunduk pada upaya hukum biasa maupun luar biasa. ${ }^{36}$

Dari hasil wawancara tersebut dapat kita analisis bahwa keinginan dan upaya yang dilakukan para hakim di Pengadilan Agama untuk mengintegrasikan upaya mediasi di Pengadilan sudah cukup baik, namun tidak sepenuhnya berhasil dengan baik karena kendala-kendala yang terdapat di lapangan seperti ketidakhadiran kedua belah pihak dalam proses persidangan menjadi faktor utama tidak dapat dilakukannya mediasi oleh hakim. Faktor lainnya adalah kesadaran hukum para pihak terhadap arti penting dilakukannya proses mediasi sebelum masuk ke pokok perkara juga masih kurang. Oleh sebab itu perlu terus ditingkatkan upaya-upaya pengenalan cara penyelesaian secara mediasi ini kepada masyarakat secara luas, bisa melalui penyuluhan hukum ataupun mengikutsertakan masyarakat dalam pelatihan-pelatihan mediasi.

Untuk mendukung terlaksananya mediasi di Pengadilan tentu harus didukung oleh adanya sarana dan prasarana yang baik serta ketersediaan mediator yang bersertifikat dalam menyelesaikan kasus tersebut. Berdasarkan hasil wawancara dengan hakim di atas, beliau menjelaskan bahwa mediator yang ada di Pengadilan Agama Bangkinang yaitu semua Hakim yang ada di lingkungan Pengadilan Agama saja. Jumlah Mediator 8 Hakim Mediator, diantaranya 2 Hakim Mediator yang bersertifikat; dan 6 Hakim Mediator yang belum bersertifikat.

Dalam Pasal 8 PERMA Nomor 1 Tahun 2008 disebutkan bahwa yang dapat menjadi mediator di Pengadilan adalah: 1) Hakim bukan pemeriksa perkara; 2) Advokat atau akademisi hukum;3) Profesi non hukum;4) Hakim Majelis pemeriksa perkara.

Jadi dapat kita lihat mediator di Pengadilan Agama hanya berasal dari kalangan hakim, belum ada dari kalangan advokat, profesi non hukum dan akademisi. Untuk lancarnya proses mediasi di Pengadilan Agama maka perlu kiranya Pengadilan Agama mensosialisasikan tentang keberadaan mediasi di Pengadilan supaya pihakpihak yang bukan dari kalangan hakim dapat berpartisipasi untuk menjadi mediator di Pengadilan Agama Bangkinang.

Terkait dengan sarana dan prasarana mediasi di Pengadilan Agama Bangkinang berdasarkan hasil wawancara, Sulem Ahmad menyatakan bahwa sarana dan

${ }^{36}$ Pasal 1 ayat (2) PERMA 01/2008 tentang Prosedur Mediasi di Pengadilan 
prasarana masih belum memadai, karena Kantor Pengadilan Agama Bangkinang masih dibangun ulang, dan seharusnya ada ruang mediasi. Sekarang kantor Pengadilan Agama Bangkinang berada menumpang bangunan di dinas koperasi yang memanfaatkan ruangan yang ada, baik ruangan hakim dan ruang pertemuan biasa. ${ }^{37}$

Dari keterangan yang telah disampaikan dapat disimpulkan tentang kendalakendala yang terjadi di lapangan terkait dengan mediasi perceraian di Pengadilan Agama: 1. mediasi tidak berjalan dengan baik karena hadirnya salah satu pihak dalam proses perkara di Pengadilan; 2 . pengetahuan para pihak tentang mediasi di pengadilan masih kurang; 3 . jumlah mediator hanya dari kalangan hakim; 4. sarana dan prasarana ruang yang tidak memadai; 5 . sarana dan prasarana peralatan kantor untuk proses mediasi tidak memadai; 6 . masih kurang mediator bersertifikat di Pengadilan Agama Bangkinang.

Kendala-kendala yang terjadi tentu saja menyebabkan tingkat keberhasilan penyelesaian sengketa secara mediasi menjadi belum maksimal, oleh sebab itu Ketua Pengadilan Agama Bangkinang perlu segera menginventaris kendala tersebut, serta melakukan upaya-upaya untuk mengatasi kendala-kendala yang ada melalui program kerja yang akan direncanakan setiap tahunnya.

Sebagai data pendukung berikut terdapat mengenai gambaran umum tentang perkara yang dilakukan dengan mediasi, adalah sebagai berikut:

Tabel 2

Gambaran Umum Sampel Penyelesaian Perkara dengan Mediasi

\begin{tabular}{|c|c|c|c|c|c|c|}
\hline Periode & $\begin{array}{c}\text { Jumlah } \\
\text { Perkara } \\
\text { terakhir }\end{array}$ & $\begin{array}{c}\text { Perkara } \\
\text { masuk }\end{array}$ & $\begin{array}{c}\text { Tidak } \\
\text { Bisa } \\
\text { Mediasi }\end{array}$ & Mediasi & Berhasil & $\begin{array}{c}\text { Tidak } \\
\text { Berhasil }\end{array}$ \\
\hline Agustus 2013 & 62 & 56 & 36 & 12 & 0 & 12 \\
September 2013 & 118 & 67 & 56 & 13 & 3 & 10 \\
\hline
\end{tabular}

Sumber Data: Pengadilan Agama Bangkinang 2013

Dari tabel di atas memang tidak semuanya kasus tentang keberhasilan mediasi terkait masalah perceraian. Akan tetapi secara umum proses mediasi yang dilaksanakan dengan kehadiran para pihak tingkat keberhasilannya cukup baik. Hal ini tentu perlu ditingkatkan oleh para mediator di Pengadilan Agama Bangkinang.

\footnotetext{
${ }^{37}$ Wawancara dengan Drs. Sulem Ahmad, SH., MA,..., Loc.Cit.
} 
Model mediasi yang biasa di lakukan di Pengadilan Agama Bangkinang adalah Evaluative mediation, hal ini terjadi karena mediator adalah para hakim yang berada di lingkungan Pengadilan Agama Bangkinang. Supaya model mediasi yang digunakan dapat beragam, maka keberadaan mediator bersertifikat dari kalangan lainnya perlu ditingkatkan.

\section{Mediasi di Luar Pengadilan di Kabupaten Kampar}

Penelitian ini dilakukan di dua Kecamatan di Kabupaten Kampar, yaitu di Kecamatan Tambang dan Kecamatan Kampar. Proses mediasi dibagi ke dalam tiga tahap, yaitu ta-hap pramediasi, tahap pelaksanaan mediasi, dan tahap akhir implementasi hasil mediasi. Ketiga tahap ini merupakan jalan yang akan ditempuh oleh mediator dan para pihak dalam menyelesaikan sengketa mereka. ${ }^{38}$

Tahap pramediasi adalah tahap awal di mana mediator menyusun sejumlah langkah dan persiapan sebelum mediasi benar-benar dimulai. Tahap pramediasi merupakan tahap amat penting, karena akan menentu-kan berjalan tidaknya proses mediasi selanjutnya. Pada tahap ini mediator melakukan beberapa langkah antara lain; membangun kepercayaan diri, menghubungi para pihak, menggali dan memberikan informasi awal mediasi, fokus pada masa depan, mengoordinasikan pihak bertikai, mewaspadai perbedaan budaya, menentukan siapa yang hadir, menentukan tujuan pertemuan, kesepakatan waktu dan tempat, dan menciptakan rasa aman bagi kedua belah pihak untuk bertemu dan membicarakan perselisihan mereka. ${ }^{39}$

Tahap pelaksanaan mediasi adalah tahap di mana pihak-pihak yang bertikai setelah berhadapan satu sama lain, dan memulai proses mediasi. Dalam tahap ini, terdapat beberapa langkah penting antara lain; sambutan pendahuluan mediator, presentasi dan pemaparan kisah para pihak, mengurutkan dan menjernihkan permasalahan, berdiskusi dan negosiasi masalah yang disepakati, menciptakan opsiopsi, menemukan butir kesepakatan dan merumuskan keputusan, mencatat dan menuturkan kembali keputusan, dan penutup mediasi.

Terakhir tahap akhir implementasi hasil mediasi yang merupakan tahap di mana para pihak hanyalah menjalankan hasil-hasil kesepakatan, yang telah mereka

\footnotetext{
${ }^{38}$ Sahrizal Abbas, Op.Cit., hlm. 36.

${ }^{39}$ Ronal S. Kraybill, Alice Frazer Evans dan Robert A. Evans, Peace Skills, Panduan Mediator Terampil Membangun Perdamaian, Penerbit Kanisius, Yogyakarta, 2006, hlm. 63-67. Sebagaimana dikutip oleh Sahrizal Abbas, Ibid.
} 
tuangkan bersama dalam suatu perjanjian tertulis. Para pihak menjalankan hasil kesepakatan berdasarkan komitmen yang telah mereka tunjukan selama dalam proses mediasi. Umumnya, pelaksanaan hasil mediasi dilakukan oleh para pihak sendiri, tetapi tidak tertutup kemungkinan juga ada bantuan pihak lain untuk mewujudkan kesepakatan atau perjanjian tertulis. Keberadaan hak lain disini hanyalah sekadar membantu menjalani hasil kesepakatan tertulis, setelah ia mendapatkan persetujuan dari kedua belah pihak.

Pada Kecamatan Kampar, berdasarkan hasil wawancara dengan Datuk Haji Jasmiran, ${ }^{40}$ menyatakan bahwa pernah melakukan mediasi perceraian pada 2012 sejumlah 2 perkara. Permasalahannya adalah adanya campur tangan mertua dalam rumah tangga yang bersangkutan dan terkait masalah kenakalan anak-anak mereka. Yang terlibat dalam proses mediasi adalah paman dari masing-masing pihak beserta ninik mamak dari suku tersebut. Mediasi dilakukan dengan memanggil para pihak beserta pamannya, kemudian diundang untuk mediasi di rumah ninik mamak atau kepala suku tersebut. Proses mediasi dilakukan dengan: 1. Pada pertemuan pertama kepala suku memanggil mamak atau paman masing-masing pihak karena para pihak sudah menjelaskan kepada pamannya untuk menyelesaikan. Dalam istilah adat "kemenakan yang berbuat, pamanlah harus bertanggung jawab untuk menyelesaikannya"; 2. Pertemuan kedua memanggil para pihak yang bersengketa untuk dinasehati tentang hukum perkawinan dan diminta untuk berdamai. Apabila para pihak sepakat untuk berdamai maka dilanjutkan untuk pertemuan ketiga; 3 . Pada pertemuan ketiga acara silaturahmi atau acara duduk bersama antara seluruh keluarga dan ninik mamak untuk mendoa atas kelangsungan dan kebaikan rumah tangga mereka di kemudian hari.

Dalam mediasi memang bersifat rahasia dari masyarakat, namun pihak keluarga, terutama paman dari masing-masing pihak harus mengetahui persoalan kemenakannya supaya bisa diberi nasehat yang baik. Dalam proses mediasi tidak dibuat notulensi secara tertulis. Hasil kesepakatan para pihak adalah perdamaian dan tidak melanjutkan perkara ke pengadilan.

Sedangkan di Kecamatan Tambang pada 2011 sampai dengan akhir 2012, data perkara yang diterima atau di proses oleh ninik mamak Desa Kualu Kecamatan Tambang Kabupaten Kampar, menyebutkan, untuk 2012 periode Januari - November,

${ }^{40}$ Wawancara dengan Datuk Haji Jasmiran, kepada Persukuan Domo, tanggal 29 Oktober 2013. 
gugat cerai yang masuk mencapai 7 perkara, 5 diantaranya di selesaikan secara mediasi oleh ninik mamak sehingga bisa Rujuk kembali, dan 2 diantaranya masuk ke Pengadilan Agama Kampar. Jumlah di 2012 ini jauh meningkat dibandingkan tahun sebelumnya (2011), di mana jumlah gugat cerai yang masuk atau diproses oleh ninik mamak masih berkisar 3 atau 4 perkara. Dari hasil evaluasi oleh ninik mamak Desa Kualu Kecamatan Tambang Kabupaten Kampar, menurut H. Anwar. HS, Datuk Panglimo Rajo, mengatakan dominasi gugat cerai masih berada pada pihak wanita. Sementara untuk kasus rumah tangganya, kebanyakan disebabkan oleh perekonomian keluarga yang lemah serta mentalitas moral yang masih belum begitu siap untuk membentuk rumah tangga. ${ }^{41}$

Dari pelaksanaan proses mediasi yang dilakukan oleh ninik mamak di Kecamatan Tambang Kabupaten Kampar berjalan dengan cukup baik. Tahapan proses mediasi dilakukan, pada tahap persiapan mediasi paman dari masing-masing pihak melapor kepada ninik mamak, kemudian ninik mamak menentukan waktu dan tempat mediasi, setelah itu barulah mengundang para pihak untuk hadir dalam proses mediasi.

Dalam tahap pelaksanaan ninik mamak membuka acara mediasi, kemudian para pihak memaparkan persoalan yang terjadi di antara mereka, barulah ninik mamak memberikan nasehat-nasehat perkawinan dan meminta kepada para pihak untuk berdamai. Dalam tahap akhir mediasi ninik mamak membuat notulensi hasil mediasi tetapi dalam bahasa daerah (bahasa Ocu). Dari hasil mediasi yang telah dilakukan biasanya para pihak sepakat untuk melakukan perdamaian, sehingga tidak terjadi perceraian. ${ }^{42}$

Jika dianalis model mediasi yang digunakan dalam penyelesaian di luar pengadilan ini adalah model settlement mediation. model ini dikenal sebagai mediasi komp-romi merupakan mediasi yang tujuan utamanya adalah untuk mendorong terwujudnya kompromi dari tuntutan kedua belah pihak yang sedang bertikai. Dalam mediasi model ini, tipe mediator yang dikehendaki adalah yang berstatus tinggi, sekalipun tidak terlalu ahli dalam proses dan teknik-teknik mediasi. Adapun peran yang dapat dimainkan oleh mediator adalah menentukan "bottom lines" dari disputan dan secara persuasif mendorong kedua belah pihak bertikai untuk samasama menurunkan posisi mereka ke titik kompromi. Dalam hal ini mediator yang

\footnotetext{
${ }^{41}$ Abdul Salam, Op.Cit., hlm. 13.

${ }^{42}$ Ibid., hlm. 56-63.
} 
dimaksud adalah ninik mamak atau kepala suku adat, yang memiliki peran yang sangat besar dalam mengatur kehidupan masyarakat di persukuannya.

Ninik mamak memiliki peran penting dalam menjaga ketertiban dalam masyarakat, dan sebagai pihak yang memiliki kewenangan dalam menyelesaikan perkara di luar pengadilan salah satunya melalui mediasi ini, maka peran ini tentu perlu ditingkatkan. Peningkatan peran ninik mamak ini dapat dilakukan dengan memberikan pendidikan mediasi kepada para ninik mamak. Karena pelatihan mediasi yang dilaksanakan oleh Mahkamah Agung, maka kerja sama pemerintah daerah dalam membina dan mengembangkan peran ninik mamak dalam masyarakat terutama dalam menyelesaikan sengketa yang terjadi dalam masyarakat melalui mediasi perlu dilakukan.

\section{Kelebihan dan Kekurangan Mediasi}

Dari hasil penelitian yang dilakukan dalam penyelesaian sengketa secara mediasi untuk kasus perceraian di Kabupaten Kampar baik di Pengadilan Agama maupun di luar pengadilan, responden menjawab bahwa kelebihan mediasi adalah sebagai berikut: 1 . bersifat rahasia; tidak diketahui secara luas oleh masyarakat, baik mediasi di Pengadilan maupun di luar pengadilan. Karena kasus perceraian adalah kasus yang sangat dirahasiakan oleh para pihak supaya persoalan rumah tangga mereka tidak diketahui khalayak umum; 2. tidak memakan biaya yang besar; dalam proses mediasi di luar pengadilan, para pihak hanya menyediakan makanan ala kadarnya untuk menjamu ninik mamak dalam proses mediasi. Itupun tidak ada kewajiban untuk menjamu para ninik mamak tersebut, dan ninik mamak sebagai mediator tidak dibayar untuk menyelesaikan masalah tersebut; 3. rasa kekeluargaan dapat tumbuh kembali; karena dalam proses mediasi dengan menghadirkan mamak atau paman masing-masing pihak dan ninik mamak sebagai mediator biasanya para pihak dapat berbaikan kembali karena rasa segan dan menghormati para tetua adat dan untuk menjaga nama baik keluarga besar kedua belah pihak; 4. mediasi memberikan kesempatan pada para pihak untuk berpartisipasi secara langsung dan secara informal dalam menyelesaikan sengketa; dalam mediasi para pihak selalu diminta untuk mengemukakan pendapat dan menjelaskan apa yang menjadi persoalan di antara mereka; 5. mediasi dapat mengubah hasil, dengan suatu kepastian melalui consensus; kesepakatan yang dihasilkan biasanya adalah perdamaian, sehingga pihak yang tadinya ingin bercerai dapat mengurungkan 
niatnya untuk bercerai; 6. mediasi mampu menghilangkan konflik; dengan nasehatnasehat perkawinan yang diberikan oleh mediator, membuat para pihak menyadari kesalahan dan kekurangan masing-masing dan berjanji untuk tidak mengulangi lagi.

Sedangkan kekurangan dalam proses mediasi adalah: 1 . karena rasa segan ke ninik mamak dan paman, tidak menukik pada akar masalah; 2. lebih dominan ninik mamak dalam mengemukakan pendapat; 3. relatif tidak ada kepastian hari untuk bertemu karena harus menyesuaikan dengan jadwal ninik mamak dan paman masing-masing pihak; 4. notulensi tidak tercatat secara sistematis bahkan bersifat lisan.

\section{Penutup}

Penelitian ini menyimpulkan, pertama, penyelesaian sengketa perceraian secara mediasi di Pengadilan Agama Bangkinang belum berjalan maksimal dimana dalam setiap perkara yang masuk ke Pengadilan Agama Bangkinang memang diupayakan proses mediasi terlebih dahulu. Akan tetapi masih terdapat kendala-kendala di lapangan seperti: Mediasi tidak dapat berjalan jika tidak hadirnya salah satu pihak dalam proses perkara di Pengadilan, Pengetahuan para pihak tentang mediasi di pengadilan masih kurang, Jumlah mediator hanya dari kalangan hakim, sarana, dan prasarana ruang yang tidak memadai, Sarana dan prasarana peralatan kantor untuk proses mediasi tidak memadai, Masih kurang mediator bersertifikat di Pengadilan Agama bangkinang.

Kedua, penyelesaian sengketa perceraian secara mediasi di luar pengadilan di Kabupaten Kampar sudah cukup baik karena mediatornya adalah ninik mamak dari persukuan para pihak ditambah dengan mamak atau paman dari masingmasing pihak. Secara emosional mereka terikat hubungan yang baik dengan para mediator, dan rasa segan kepada para mediator membuat para pihak dapat menurunkan emosi dan mendengarkan nasehat mediator atas persoalan rumah tangga yang mereka hadapi.

Ketiga, kelebihan dan kekurangan dalam proses mediasi dalam kasus perceraian di Kabupaten kampar adalah sebagai berikut. Untuk kelebihan antara lain: proses mediasi bersifat rahasia, tidak memakan biaya yang besar, rasa kekeluargaan dapat tumbuh kembali, mediasi memberikan kesempatan pada para pihak untuk 
berpartisipasi secara langsung dan secara informal dalam menyelesaikan sengketa, Mediasi dapat mengubah hasil, dengan suatu kepastian melalui consensus, mediasi mampu menghilangkan konflik. Sedangkan kekurangan dalam proses mediasi adalah: Karena rasa segan ke ninik mamak dan paman, tidak menukik pada akar masalah. Lebih dominan ninik mamak dalam mengemukakan pendapat, relatif tidak ada kepastian hari untuk bertemu karena harus menyesuaikan dengan jadwal ninik mamak dan paman masing-masing pihak. Notulensi tidak tercatat secara sistematis bahkan ada yang secara lisan.

Oleh sebab itu diharapkan Pengadilan Agama Bangkinang di samping melakukan sosialisasi terhadap proses penyelesaian sengketa secara mediasi di Pengadilan Agama Bangkinang supaya para pihak yang berperkara akan menempuh jalur mediasi terlebih dahulu sebelum masuk pada pemeriksaan pokok perkara, di samping itu diharapkan peran mediator bersertifikat selain dari hakim Pengadilan Agama Bangkinang untuk mendaftarkan diri sebagai mediator di Pengadilan Agama Bangkinang, melengkapi sarana dan prasarana mediasi di Pengadilan Agama Bangkinang.

Proses penyelesaian secara mediasi di luar pengadilan perlu digalakkan karena dengan adanya penyelesaian sengketa perceraian secara mediasi di luar pengadilan tentu saja akan menurunkan tingkat perceraian dalam masyarakat. Mediator di luar Pengadilan diharapkan membuat notulensi secara sistematis dan terjadwal dengan baik, dan apabila memungkinkan para mediator atau ninik mamak dapat mengikuti pelatihan tentang mediasi yang diadakan oleh perguruan tinggi ataupun lembagalembaga negara lainnya.

\section{Daftar Pustaka}

Abbas, Syahrizal, "Mediasi dalam Persfektif Hukum Syariah, Hukum Adat, dan Hukum Nasional”, Kencana Prenada Media Group, Jakarta, 2009.

Dewi, D.S., “Implementasi PERMA Nomor 1 Tahun 2008 Tentang Prosedur Mediasi Pengadilan", makalah pada Pelatihan Mediator yang diselenggarakan oleh IICT bekerjasama dengan Fakultas Hukum Universitas Riau, 2011.

HS., Salim, "Pengantar Hukum perdata tertulis (BW)”, Sinar Grafika, Jakarta, 2005.

Mertokusumo, Sudikno, Sejarah peradilan dan perundang-undangannya di Indonesia sejak 1942, PT Gunung Agung, 1973. 
"Sistem Peradilan di Indonesia", 24 Maret 2008, http://sudiknoartikel. blogspot.com/2008/03/sistem-peradilan-di-indonesia.html, diakses 29 November 2013.

Mahkamah Agung RI., Mediasi dan Perdamaian, MA-RI, Jakarta, 2004, sebagaimana dikutip oleh Nurnaningsih Amriani, 2012, "Mediasi Alternatif Penyelesaian Sengketa Perdata di Pengadilan", RajaGrafindo Persada, Jakarta.

Marzuki, Peter Mahmud, Pengantar Ilmu Hukum, Prenada Media Group, Jakarta, 2009.

Prodjohamidjojo, Martiman, "Hukum Perkawinan dalam Tanya Jawab", Cetakan Keenam, Indonesia Legal Center Publishing, Jakarta, 2011.

Sunggono, Bambang, “Metode Penelitian Hukum”, RajaGrafindo Persada, Jakarta, 1996.

Salam, Abdul, "Pelaksanaan Mediasi dalam Perkara Perceraian pada Masyarakat Adat di Desa Kualu Kecamatan Tambang Kabupaten Kampar", Skripsi, Pekanbaru, 2013.

Tim Penyusun Kamus Pusat Pembinaan dan Pengembangan Bahasa, "Kamus Besar Bahasa Indonesia", Departemen Pendidikan dan Ke-budayaan, Jakarta,1988.

Undang-Undang Nomor 1 Tahun 1974 tentang Perkawinan.

Undang-Undang Nomr 30 Tahun 1999 tentang Arbitrase dan Alternatif Penyelesaian Sengketa.

Kompilasi Hukum Islam.

Peraturan Mahkamah Agung No. 1 Tahun 2008 tentang Mediasi di Pengadilan.

Wawancara dengan Datuk Haji Jasmiran, kepala Persukuan Domo.

Wawancara dengan Tommy Andesta Siahaan, Staf Biro Hukum Pengadilan Agama Bangkinang.

Wawancara dengan Drs. Sulem Ahmad, SH., MA, Hakim Mediator bersertifikat. 